\title{
Tradisi dalam Modernisasi Seni Lukis Sumatera Utara: Eksplorasi Kreatif Berbasis Etnisitas Batak Toba
}

\author{
Zulkifli', Dermawan Sembiring, Wahyu Tri Atmojo, Mangatas Pasaribu \\ Jurusan Seni Rupa, Fakultas Bahasa dan Seni, Universitas Negeri Medan \\ Izulkiflifbs@unimed.ac.id
}

\begin{abstract}
Artikel ini membahas tentang sejauhmana potensi nilai dan karakter tradisional dapat dikembangkan sebagai tema garapan dalam eksplorasi kreatif seni lukis masa kini. Artikel berbasis hasil penelitian terapan ini, bertujuan menemukan bentuk dan wujud seni rupa tradisi yang khas, khususnya dari etnik Batak Toba, untuk dikembangkan secara kreatif dalam garapan seni lukis Sumatera Utara. Tujuan dimaksud diwujudkan melalui aplikasi teknologi digital serta rekayasa media dan peralatan melukis. Metode yang digunakan adalah survey dan metode penciptaan kreatif, mulai persiapan, inkubasi, iluminasi, eksekusi, konfirmasi, dan validasi. Analisis data disajikan dalam bentuk deskriptif kualitatif. Hasil penelitian menunjukan bahwa eksplorasi seni lukis modern Sumatera Utara melahirkan karakter bentuk orisinil, sebagai penanda jati diri dan promosi budaya rupa etnik Batak Toba. Karakter seni lukis eksploratif ini berkontribusi pada pengayaan budaya rupa nasional. Hasil penelitian juga menemukan efektivitas penggunakan teknologi digital dan rekayasa media seni lukis, sebagai stimulasi penggunaan media alternatif dalam pengembangan model industri kreatif.
\end{abstract}

Kata kunci: tradisi, modernisasi, seni lukis, kreatif, etnis Batak

\section{Tradition in the Modernization of the Painting Art of North Sumatera: A Creative Exploration Based on the Ethnicity of Batak Toba}

This article discusses the potential of traditional value and character that can be developed as a theme in the creative exploration of today's fine arts. This article which is a result of an applied research aimed to find unique shapes and forms from mainly the ethnicity of Batak Toba to be creatively developed in North Sumatera painting art. This is done by using digital technology application as well as engineering of the media and the equipment for painting. This research used survey and creative exploration method starting from the preparation, incubation, illumination, execution, confirmation and validation. The results of this research shows that this exploration of North Sumatera painting art created original shape character as an identity marker and a promotion of the visual culture of Batak Toba. The character of this explorative art of painting contributes to the enrichment of national visual culture. This research also found the effectivity in the use of digital media and the engineering of the media or painting as a stimulation of the use of alternative media in the development of creative industry.

Key words: tradition, modernization, painting art, creative, Batak ethnic

Proses Review : 18 - 31 Agustus 2020, Dinyatakan Lolos: 7 September 2020 


\section{PENDAHULUAN}

Fenomena kehidupan sosial masyarakat etnik di Indonesia berada di persimpangan. Nilai-nilai yang selama ini diagungkan, yang menjadi bagian dalam kehidupan sosial budaya masyarakat mengalami kegoncangan, dengan masuknya unsur budaya asing yang kemudian mendoninasi kebudayaan lokal (Sachari, 2007:6). Salah satu penyebab perubahan budaya adalah terjadinya kontak dengan bangsa (budaya) lain (Yulinis, 2019: 275). Kebudayaan lokal atau etnik yang masih ada umumnya hanyalah berupa seremonial, yang disesuaikan dengan kondisi dan situasi zaman yang sudah berubah. Kondisi ini didorong oleh pola hidup dan tata kehidupan yang senantiasa mengedepankan aspek kepraktisan, berorientasi pada hasil yang efisien dan efektif. Segala sesuatu diukur secara rasional dengan pertimbangan kalkulatif. Akibatnya nilai-nilai budaya etnik, budaya tradisi semakin sulit dipertahankan.

Secara spesifik, kondisi ini terlihat pada budaya visual dan dunia kesenirupaan etnik di Sumatera Utara. Banyak artefak budaya rupa etnik atau tradisi yang tidak mudah lagi ditemui sekarang. Disamping sebagian pernah dilarang penggunaannya oleh misionaris Kristen, sebagian yang lain adalah karena memang tidak digunakan masyarakat dalam kehidupan praktis. Dalam pertimbangan praktis dan ekonomis, produk budaya etnik mungkin tidak relevan lagi, dan itu dapat dimaklumi. Namun dalam konteks spiritualitas, spirit masa lalu mestinya dapat terus dikembangkan. Nilai-nilai budaya etnik (tradisi) masa lalu mestinya dapat dikontekstualisasikan dengan kemajuan zaman dan modernisasi sekarang melalui upaya konservasi. Dalam konteks penelitian ini, diperlukan upaya konservasi melalui eksplorasi kreatif, agar dapat melestarikan dan mengembangkan bentuk-bentuk ertefak budaya etnik dalam bentuknya yang baru. Artefak budaya, sama halnya dengan kesenian secara umum, merupakan sesuatu yang kompleks dalam hal ide, gagasan, dan nilai-nilai yang diproduksi secara kreatif (Sofyan, dkk., 2018:393). Yang dibutuhkan adalah inisiatif dan sikap kreatif, karena masa depan adalah masa lalu yang kreatif (Dharsono, 2018:18).

Salah satu Etnik di Sumatera Utara adalah Batak Toba, yang memiliki kekayaan budaya rupa tradisi yang khas. Perlu dilakukan upaya konservasi untuk pelestariannya melalui berbagai alternatif pengembangan. Menghadirkan idiom tradisi dalam wujudnya yang baru tidak lagi berupa penuangan ide seraca tematik, tetapi sebagai simbol tekstual bagi kebebasan tafsir (Harissman dan Suryanti, 2019:55). Dalam penelitian ini, dilakukan melalui esplorasi seni lukis berbasis teknologi digital dan media alternatif barupa matra karet dengan alat penghantar panas. Budaya rupa atau bentuk-bentuk artefak seni rupa tradisi Batak Toba masa lalu dalam format dan tampilannya yang baru akan tetap menjadi identitas dan penanda jadi diri masyarakatnya. Pelestarian seni rupa etnik tradisi ini adalah sebagai bentuk ketahanan budaya (Dharsono, 2018:18).
Disamping sebagai mekanisme ketahanan budaya, adalah sebagai penyeimbang di tengah maraknya produk budaya populer yang mengandung unsur budaya asing. Di era pluralisme budaya kontemporer sekarang, seni rupa etnik dapat hidup berdampingan dalam khasanah keragaman seni rupa dunia. Selanjutnya, berdasarkan permasalahan yang digambarkan di atas, secara spesifik tujuan penelitian ini adalah: 1) Menemukan bentuk-bentuk kreatif seni lukis Sumatera Utara yang orisinil; 2) Mengetahui efektivitas penggunaan media digital untuk merekayasa alternatif rujukan dan media karet sebagai tafril lukisan; dan 3) Merumuskan kontribusi hasil ciptaan pada pengayaan budaya rupa lokal dan nasional, serta stimulisasi model pengembangan industri kreatif.

Untuk mendukung kajian yang lebih komprehensif, berikut dipaparkan hasil review terhadap konsep dan teori relevan, yang didukung oleh referensi dan kepustakaan terkini. Paparan ini terkait dengan bentuk-bentuk seni rupa dan ekspresi seni budaya tradisi Batak Toba yang menjadi basis pengembangan seni lukis. Kemudian, membahas tentang modernisasi seni lukis Sumatera Utara berbasis bentuk dan nilai tradisi. Pebahasan ini tidak terlepas dari aspek sosiologis seniman dan masyarakat pencinta seni. Pada bagian akhir bahasan dijelaskan perihal eksplorasi kreatif yang terkait dengan penelitian terapan ini.

\section{Seni Rupa/Budaya Tradisi Batak}

Etnik Batak Toba, secara sosiologis tinggal di sekitar Danau Toba. Secara sosial politik yang dulunya merupakan Kabupaten Tapanuli Utara, sekarang berkembang menjadi empat kabupaten, yaitu Kabupaten Samosir, Toba Samosir, Humbang Hasundutan, dan Tapanuli Utara yang merupakan induknya. Kabupaten Samosir yang wilayah utamanya di sekitar Pulau Samosir dinyatakan sebagai tempat asal masyarakat etnik Batak, yang kaya dengan seni budayanya (Zulkifli, 2016:103).

Etnik Batak Toba memiliki beragam bentuk dan wujud seni rupa masa lalu yang mentradisi sampai sekarang. Seni rupa atau seni budaya Batak masa lalu secara umum lahir dari kepercayaan masyarakatnya terhadap alam dan tuhannya (kosmologi dan teologinya) (Zulkifli, 2019:2). Sebagian dari artefak seni budaya Batak ini hampir punah, ada yang tidak dikenal lagi karena sebelumnya dilarang oleh misionaris Kristen yang datang ke Tanah Batak, dan sebagian ada juga yang disimpan di beberapa museum di Eropa. Di sisi lain, juga ada upaya untuk menginventarisasi dan mendokumentasikan keragaman bentuk dan wujud seni rupa Batak dan Sumatera Utara secara umum, seperti yang dilakukan Baginda Sirait dan Julaihi Wahid bersama Bhakti Alamsyah (Sirait, 1980:16-57; Wahid dan Alamsyah, 2013:62-102). Seni budaya Batak dalam bentuk dan wujud seni rupa etnik masa lalu, dalam penelitian ini dijadikan basis untuk pengembangan seni lukis eksploratif atau seni lukis modern Sumatera Utara. 


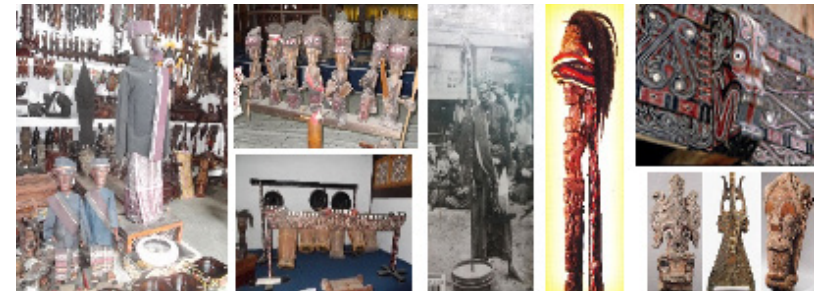

Gambar 1. Beberapa bentuk artefak seni rupa Batak Toba

(Sumber: Zulkifli, 2018; https://bfinews.com/resource/20160530-hokky-ilustrasigorga.jpg)

Keragaman seni rupa Batak masa lalu dapat dikelompokkan pada bentuk-bentuk yang sudah dipahami sebagai karya seni rupa, seperti patung, relief, ukiran, anyaman, tenunan, yang diungkapkan pada material batu, kayu, bambu, logam, tanduk, tanah liat, buah kering, benang/ serat, dan sebagainya. Bentuk seni rupa ini terungkap dalam produk-produk tradisi, seperti patung pangulubalang, boneka sigale-gale, relief tunggal panaluan, sahan, pustaha, tenunan ulos, berbagai ragam hias (gorga), dan lainnya. Seni rupa Batak Toba masa lalu (tradisi) ini semuanya tergolong seni tarapan (applied art), yang mengandung fungsi pakai dalam aktivitas sosial dan budaya masyarakat.

Lebih dari itu, secara umum kelompok yang lain adalah berupa wujud seni rupa dalam bentuk properti dan ekspresi seni tari, seni musik, sastra, dan lainnya, serta dalam properti dan ritual adat dan budaya masyarakat. Hal ini menegaskan bahwa wujud seni rupa masa lalu terintegrasi dalam ekpresi seni lainnya, dan juga dalam ritual budaya masyarakat. Misalnya bentuk alat musik, pakaian tari, dan peralatan ritual budaya lainnya. Bentuk alat musik dapat dinyatakan sebagai wujud seni rupa, seperti gondang, hasapi, dan lainya, dia menjadi alat musik ketika sedang dimainkan. Begitu juga dengan properti seni tari dan properti ritual lainnya.

Kekayaan dan keragaman bentuk dan wujud seni rupa tradisi Batak Toba di atas, dijadikan basis pengembangan seni lukis modern Sumatera Utara, untuk melihat bagaimana dampaknya terhadap kualitas penciptaan dan khasanah kesenilukisan Indonesia. Modernisasi seni lukis berbasis bentuk seni rupa tradisi/etnik ini, didukung oleh teknologi digital untuk mengekplorasi alternatif rujukan. Kemudian, rujukan tema dan objek lukisan ditransfer ke tafril lukisan dengan mengaplikasikan matra karet, yang diolah dengan alat penghantar panas.

\section{Modernisasi Seni Lukis Sumatera Utara}

Sejalan dengan perkembangan seni lukis secara umum di Indonesia, di Sumatera Utara dengan pusatnya kota Medan juga bekembang gerakan seni rupa atau seni lukis modern. Tentunya modernisasi seni lukis Sumatera Utara ini tidak dapat sepenuhnya diidentikkan dengan seni rupa Modern dari pusat utama kelahiran dan perkembangannya. Sebagaimana arogansi Barat selama ini, seni lukis (seni rupa) modern yang diakuinya hanyalah yang berkembang di Eropa Barat dan Amerika Utara (Ero-Amerikasentris). Permasalahannya terletak pada ketimpangan perkembangan sains dan teknologi negara non-Barat (negara berkembang) dengan negara Barat yang mempelopori modernisasi di segala bidang (Djatiprambudi, 2007:94).

Seni rupa modern lahir dari paradigma estetik pemikiran Barat yang sejalan dengan perkembangan sains dan teknologinya, yang secara dialektikal telah melahirkan berbagai aliran dan gaya seni rupa. Seni rupa modern ini mengadung kecenderungan prinsip: kemurnian bentuk, seni untuk seni, otentik, orisinil, dan universal (Burhan, 2018:1). Sejalan dengan perkembangan filsafat dan ilmu pengetahuan di Barat, yang berupaya secara logis memandang suatu realitas, dalam seni rupanya juga berupaya untuk merepresentasikan realitas yang objektif. Prinsip estetik seni rupa modern mengacu pada upaya merepresentasikan nilai-nilai kebentukan, sebagai sesuatu yang bertolak belakang dengan prinsip estetik seni rupa kontemporer yang berupaya mempresentasikan ide atau gagasan, dengan nuansa satiris (Burhan, 2018:3-4)

Seni lukis modern Sumatera Utara, identik dengan kenyataan seni lukis Indonesia secara umum, dan negara nonBarat lainnya, adalah seni lukis modern dalam "tanda petik" atau "tanda tanya". Namun demikian, walaupun tidak diakui sepenuhnya sebagai seni lukis (seni rupa) modern, kecenderungan gaya dan teknik yang dikembangkan seniman Sumatera Utara mengacu pada perkembangan seni lukis modern, misalnya seni lukis impresionis, surealis, kubistis, dan bentuk abstrak. Seni rupa modern Sumatera Utara dapat dinyatakan sebagai seni rupa modern yang besifat hibrid, yaitu hibridasi seni rupa modern Barat dengan sintesis nilai-nilai budaya lokal. Bentuk hibridasi ini dinyatakan sebagai the other of modernism (Burhan, 2018:1).

Perkembangan seni lukis modern di Sumatera Utara dimulai semenjak sikitar tahun 1938, ditandai dengan kedatangan beberapa pelukis dari Sumatera Barat ke Medan, seperti Nawi Butun, Ismail Sulaiman, dan Sutan Buyung. Semenjak itu, kegiatan melukis semakin berkembang, terlebih setelah berdirinya kelompok Angkatan Seni Rupa Indonesia (ASRI 45) November 1945 di Medan (Triyanto, dkk., 2015:32). Perkembangan berikutnya ditandai dengan terbentuknya wadah perkumpulan seniman yang bernama Simpaian Seniman Seni Rupa Indonesia (SIMPASSRI) Medan tahun 1967, dan sebelumnya berdiri lembaga pendidikan formal kesenirupaan yaitu Jurusan Seni Rupa IKIP Medan (sekarang Universitas Negeri Medan (Unimed)) tahun 1965 (Diskusi dengan Fuad Erdansyah, ketua SIMPASRI, 18 Juli 2019). Dengan adanya lembaga pendikan tinggi kesenirupaan di Medan tentunya perannya sangat strategis dalam meningkatkan aktivitas kesenirupan dan apresiasi masyarakat di Sumatera Utara.

Aktivitas kesenilukisan di Sumatera Utara semakin dinamis. Media yang digunakan pelukis umumnya adalah me- 
dia pupuler sebagaimana dalam perkembangan seni rupa Barat, yaitu menggunakan cat minyak pada kanvas, atau cat air pada kertas. Namun, tema sebagai subject matter banyak diambil dari unsur dan bentuk lokal, yang dapat dinyatakan sebagai modernisasi yang bersifat hibrid. Beberapa pelukis Sumatera Utara sering tampil di ajang seni lukis nasional, seperti Syahruddin Harahap, Handono Hadi, Mangatas Pasribu, dan lainnya. Dalam perkembangannya, beberapa pelukis berupaya melakukan eksplorasi kreatif dari segi media, bahan, alat, dan tampilan karya, sehingga memberi nuansa yang berbeda dengan seni lukis modern pada umumnya. Contoh yang menonjol misalnya pengembangan seni lukis pasir oleh pelukis Winarto Kartupat. Dalam perspektif sosiologi seni rupa (seni lukis) Indonesia, tokoh Persagi, S. Sudjojono lahir di Kisaran, Sumatera Utara, begitu juga dengan penggiat seni lukis anak Tino Sidin.

Dalam penelitian ini, seni lukis modern Sumatera Utara yang dikembangkan adalah yang mengukuhkan nilai dan bentuk lokal, dimana tema dan bentuk yang dikembangkan berbasis bentuk dan wujud seni rupa etnik atau tradisi Batak Toba. Untuk memberi nilai tambah dalam hal konsep dan kreativitas, bentuk seni rupa etnik sebagai rujukan dieksplorasi berbasis teknologi digital, kemudian diaplikasikan pada media karet sebagai tafril lukisan. Dengan ini, akan malahirkan karakter baru seni rupa modern Sumatera Utara, yang sejalan dengan perkembangan teknologi komputerisasi.

\section{Eksplorasi Kreatif}

Terminologi eksplorasi umumnya dipahami dalam pengertian penjelajahan atau pencarian untuk menemukan sesuatu di suatu tempat, misalnya suatu daerah, antariksa, dalam perut bumi, dan sebagainya. Lebih dari itu, terminologi ini juga sering digunakan dalam bidang kesenian untuk menggambarkan upaya pencarian yang bersifat kreatif untuk menemukan atau menghasilkan sesuatu yang baru, yang bernilai estetis. Selanjutnya, kreativitas berkaitan erat dengan konsep-konsep perbedaan, keanekaragaman, dan multiplisitas, yang akan melahirkan ide, citra, konsep, sistem, atau produk baru yang berbeda dari yang sudah ada sebelumnya. Konsep perbedaan tersebut tidak berada di ruang hampa, melainkan mengalami perubahan makna seiring waktu, apalagi dalam masyarakat dengan teknologi digital (Piliang, 2018:331).

Dalam praktiknya, kreativitas memerlukan proses yang terstruktur. Secara teoritis, proses kreatif melalui lima tahapan, yaitu: persiapan (preparation), inkubasi (incubation), penerangan (illumination), konfirmasi (confirmation), dan validasi (validation) (Wales dalam Schultz, 2003:3). Dalam penelitian ini, tahapan proses kreatif ini berlangsung dalam siklus penciptaan karya seni lukis, meliputi proses awal pengolahan secara digital bentuk-bentuk seni rupa etnik yang dijadikan sebagai referensi visual, dilanjutkan dangan proses pemindahan alternatif gambar sebagai rujukan pada matra karet yang dibentuk dengan alat penghantar panas, dan kemudian proses melukis dengan media cat minyak.

Aplikasi teknologi digital dalam eksplorasi untuk menemukan bentuk-bentuk baru yang artistik berdasarkan bentuk dan wujud kesenirupaan etnik Batak Toba sebagai alternatif objek lukisan didasari oleh pertimbangan teknis dan estetis. Secara teknis, dengan teknologi digital sangat mudah untuk melakukan pengolahan bentuk dan rekayasa visual, melahirkan perbedaan, keanekaragaman, dan multiplisitas. Kemudahan dimaksud sampai melahirkan bentuk-bentuk ekspresif artistik yang tidak terduga, yang tidak mudah dicapai dengan cara lain. Selanjutnya, penggunaan media karet sebagai tafril lukisan juga didasari oleh pertimbangan teknis dan estetis. Secara teknis, dengan media karet mudah untuk melalukan eksplorasi tekstur, yaitu tekstur yang bersifat negatif berupa citraan yang lebih dalam dari permukaan tafril, dengan menggunakan alat penghantar panas. Lebih dari itu, beragam alat yang dapat menghantarkan panas dapat digunakan untuk membentuk citra lukisan.

Eksplorasi kreatif terhadap bentuk dan wujud kesenirupaan etnik memiliki batasan dan rambu-rambu tertentu, agar keagungan dan kesakralan produk budaya etnik dapat terjaga. Upaya yang dapat dilakukan adalah dengan tetap mempertahankan karakteristik etniknya. Suatu produk etnik, produk tradisi memiliki aura tradisi, ketiga dikembangkan dalam bentuk baru, bentuk kreatif pastilah akan kehilangan aura tradisinya (istilah Benjamin: pembusukan aura) (Long, 2001:91-92). Hal ini merupakan suatu konsekuensi logis. Namun, ada upaya yang dapat dilakukan, yaitu mempertahankan karakteristiknya. Ketika eksplorasi yang dilakukan mampu mempertahankan karakteristik tradisinya, upaya tersebut dapat dimaknai sebagai eksplorasi yang melahirkan wujud kreatif. Sebaliknya, ketika eksplorasi yang dilakukan tidak mampu mempertahankan karakteristik tradisinya, maka upaya tersebut dapat dimaknai sebagai eksploitasi yang melahirkan wujud destruktif (Zulkifli, 2019:13). Oleh sebab itu, ketika seniman atau pelukis berkarya berbasis bentuk dan nilai budaya tradisi, haruslah memahami karakteristik yang sesungguhnya, sehingga dalam proses eksplorasinya tidak kehilangan jejak masa lalu dari karakteristik produk yang dirujuk.

\section{METODE PENELITIAN}

Sesuai dengan bentuknya, penelitian terapan ini menerapkan dua metode, yaitu survey dan penciptaan khusus. Metode survey diterapkan pada waktu sebelum dan setelah penciptaan karya. Survey sebelum roses penciptaan yaitu ketika mengumpulkan data seni rupa etnis Batak Toba di berbagai tempat dan sumber data: Museum Gereja Inkulturatif Pangururan dan Museum Huta Bolon Simanindo di Kabupaten Samosir; Museum TB Silalahi Center di Kota Balige, dan Museum Sumatera Utara di Medan. Sejalan 
dengan survey, juga dilakukan wawancara dengan pengelola museum, budayawan, akademisi, dan masyarakat. Survey setelah proses penciptaan yaitu untuk mendapatkan data tanggapan apresiatif ketika dilaksanakan pameran dan diskusi di Jurusan Seni Rupa Unimed, dan di Taman Budaya Medan. Lebih dari itu, adalah pada kegiatan pameran nasional yang diadakan di Taman Budaya Yogyakarta, dan diskusi dengan para perupa dan apresiator yang hadir.

Metode penciptaan khusus diterapkan dalam proses eksplorasi penciptaan karya, dengan merujuk pada teori kreativitas Graham Wales yang dikembangkan sesuai karakteristik penelitian. Metode ini menguraikan proses penciptaan dan analisisnya secara bertahap, mulai persiapan, inkubasi, iluminasi, eksekusi, konfirmasi, validasi, dan pengembangan (Wales dalam Schultz, 2003:3). Data proses penciptaan dikumpulkan melalui cacatan harian. Setelah karya selesai, pengujian kualitas estetis dilakukan melalui tanggapan apresiator berdasarkan kuesioner yang dibagikan. Secara umum, analisis data dilakukan berdasarkan metode kualitatif dan kuantitatif.

\section{HASIL DAN PEMBAHASAN}

Proses penelitian terapan ini dimulai dari penelitian lapangan menyurvey bentuk-bentuk artefak seni rupa etnik Batak Toba, termasuk wujud kesenirupaan yang terintegrasi dengan properti dan ekspresi seni budaya lainnya. Sejalan dengan itu dilakukan proses identifikasi, dokumentasi, dan inventarisasi. Hasil yang diperoleh adalah berupa berbagai bentuk patung tradisi (pangulubalang), tongkat tunggal panaluan dalam beberapa model, bentuk sahan, pustaha, berbagai kerajinan logam, tembikar, anyaman rotan/serat, tenunan ulos, ukiran pada buah labu, berbagai bentuk relief (singa-singa, ulu paung, gaja dompak, dan jenggar) berbagai ragam hias (gorga), berbagai alat musik, pakaian tradisi, senjata, dan peralatan sehari-hari masyarakat tradisi.

Berdasarkan referensi visual yang terkumpul dilakukan diskusi apresiatif tim peneliti untuk menentukan bentuk-bentuk yang paling menarik dan potensial untuk dikembangkan. Selanjutnya, dilakukan eksplorasi tahap pertama, yaitu berbasis teknologi digital dengan menggunakan program komputer untuk pengolahan gambar, yaitu program ACDSee Photo Paint dan Photoshop. Eksplorasi ini melahirkan berbagai alternatif bentuk sebagai rujukan objek lukisan. Hal ini sejalan dengan konsep perbedaan, keanekaragaman, dan multiplisitas dalam kreativitas dengan dukungan teknologi digital, sebagaimana yang disampaikan Yasraf Amir Piliang. Satu referensi visual, misalnya bentuk tongkat tunggal panaluan Batak, dapat dikembangkan menjadi 20 alternatif gambar rujukan seni lukis, dan bahkan bisa lebih. Berdasarkan puluhan alternatif ini didiskusikan lagi untuk menentukan gambar olahan digital yang paling unik dan artistik untuk dikembangkan

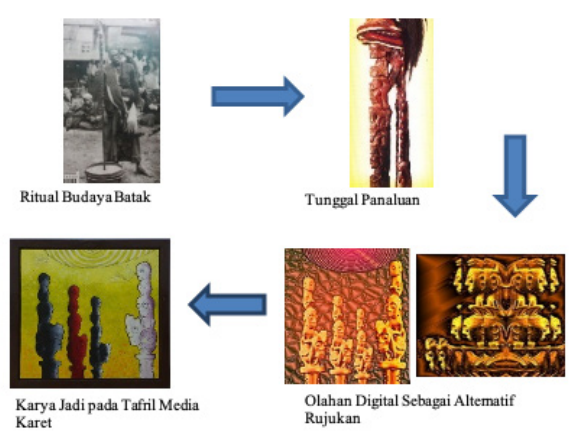

Gambar 2. Gambar alir proses penciptaan lukisan berdasarkan alternatif rujukan

(Sumber: Zulkifli, 2018)

sebagai objek seni lukis.

Eksplorasi kedua dilakukan dalam proses transfer gambar rujukan digital pada matra karet yang dijadikan sebagai tafril lukisan. Media karet diolah dengan alat penghantar panas, yang dalam penelitian ini banyak menggunakan alat solder. Dalam eksplorasi ini, pelukis yang merupakan peneliti mendapatkan momen untuk berimprovisasi dengan tekstur, karena pengolahan matra karet sejatinya adalah pengolahan tekstur dalam bentuk cekung atau rendah sebagai konsekuensi dari bekas torehan alat penghantar panas. Sejalan dengan itu adalah berimprovisasi dengan citra lukisan.

Eksplorasi ketiga adalah ketika dalam proses melukis, dengan menggunakan media cat minyak pada tafril lukisan berupa media karet. Walaupun citra lukisan sudah terbentuk mulai dari proses eksplorasi berbasis digital sampai proses transfer gambar rujukan pada matra karet, eksplorasi dan improvisasi dalam proses melukis dengan media cat minyak sangat menentukan kualitas akhir dari sebuah karya seni lukis.

Proses penelitian ini dari awal sampai akhir dicatat dalam catatan harian. Sebagai mekanisme kontrol dan evaluasi, setiap tahapan proses penelitian dilakukan diskusi tim peneliti, dan focus group discussion dengan dosen-dosen jurusan seni rupa Unimed. Pengujian kualitas estetis hasil ciptaan dilakukan melalui penilaian apresiatif oleh apresiator ketika dilaksanakan pameran, yaitu pada pameran bersama di Taman Budaya Yogyakarta tanggal 11 s/d 16 Juli 2019, dan pada pameran tim peneliti dan diskusi apresiatif di Taman Budaya Medan tanggal 18 s/d 25 Juli 2019. Hasil penilain dan tanggapan apresiatif apresiator ini dijelaskan pada sub-subbab berikut.

\section{Orisinalitas Bentuk}

Berdasarkan tanggapan apresiator dan didukung hasil analisis kuesioner yang dibagikan, karya seni lukis yang dihasilkan dalam penelitian terapan ini memiliki keaslian atau originalis. Karya seni lukis ini lahir dari proses eksplorasi kreatif, dari segi tema dan teknik. Tema sebagai subject matter dikembangkan berdasarkan bentuk-bentuk 


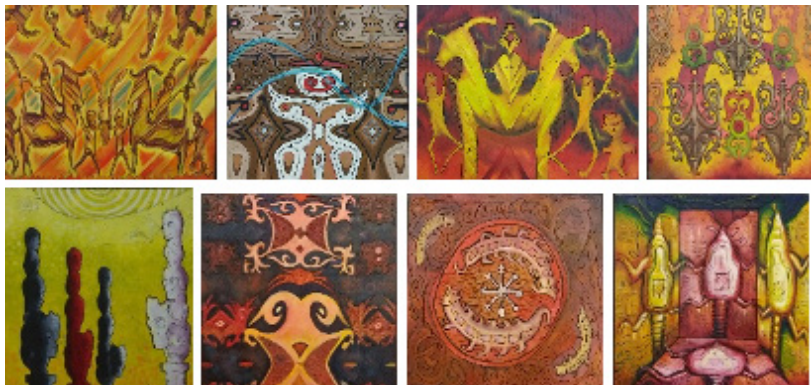

Gambar 3. Karya seni lukis berbasis bentuk-bentuk artefak seni rupa Batak Toba

(Sumber: Zulkifli, 2019)

artefak salah satu etnik di Sumatera Utara, yaitu Batak Toba. Teknis yang dikembangkan, pertama berbasis teknologi digital, dengan memanfaatkan kemajuan revolusi industri 4.0. Kedua, menggunakan media karet sebagai tafril lukisan, dan ketiga menggunakan alat penghantar panas untuk pengolahan tekstur dan citra lukisan.

Orisinalitas bentuk seni lukis ini dikembangkan dalam kerangka konsep inovasi penelitian. Konsep inovatif dimaksud adalah upaya untuk memanfaatkan modernisasi teknologi dalam rangka melestarikan dan mengembangkan bentuk-bentuk artefak budaya etnik. Artefak budaya etnik dalam pemahaman ini merupakan wujud visual, baik dalam bentuk seni rupa tradisi atau wujud seni rupa yang terintegrasi pada properti dan ekspresi seni budaya dan ritual budaya lainnya. Dapat dinyatakan bahwa, penelitian ini mengembangkan seni lukis berbasis tradisi (etnik) dengan berorientasi kekinian. Dalam bahasa lain, penelitian ini berupaya memadukan masa sekarang dan masa depan dengan masa lalu. "Masa depan adalah masa lalu yang inspiratif'.

Beberapa karya yang ditampilkan pada sampel di atas, dieksplorasi dari bentuk patung relief tunggal panaluan dan ukiran ragam hias (gorga) Batak Toba, yaitu hoda-hoda, sitompi, stilasi jenggar dan figurasi wajah. Eksplorasi seni lukis di atas memang menghilangkan aura tradisi dari bentuk artefak etnik yang menjadi basisnya, namun tetap mempertahankan karakter bentuk seni rupa etnik Batak Toba. Walaupun sudah banyak perubahan yang dilakukan melalui penyederhanaan atau pengayaan, melalui upaya imitatif atau deformatif, karakter etniknya masih dapat dikenali. Sejauhmanapun deformasi yang dilakukan seniman, apabila masih berbasis pada pamahaman terhadap bentuk-bentuk tradisi etnik yang dikembangkannya, tentunya akan dapat mempertahankan karakteristik dari bentuk rujukannya, dan tidak akan kehilangan jejak masa lalunya. Pamahaman ini tidak hanya pada aspek yang bersifat visual dan kasat mata, tetapi labih jauh menyangkut berbagai aspek konsep yang melingkupinya, yaitu filsafat, sejarah, sosiologi, kosmologi, budaya, dan berbagai nilai yang melingkupinya. Hal ini mengingat bahwa artefak etnik tidak lahir dalam kehampaan sosial, tetapi eksis dalam lingkungan sosial budaya masyarakatnya sejak lama, boleh dikatakan "seusia" dengan masyarakatnya.

\section{Efektivitas Media}

Selain menggunakan teknologi berbasis digital untuk mendapatkan alternatif rujukan lukisan, media yang dikembangkan untuk mewujudkan gagasan penciptaan dalam penelitian ini memang bukan media biasa, tetapi berupa lembaran karet (silicon rubber) sebagai pengganti kanvas. Berdasarkan hasil penelitian, media karet sebagai tafril lukisan dapat dinyatakan efektif dan berpotensi baik sebagai alternatif pengganti kanvas yang biasa dari kain yang dilapisi bahan plamir. Sesuai sifatnya, bahan karet mudah dibentuk dan dapat mempertahankan bentuk. Tidak sulit menyiapkannya karena tersedia di pasaran dalam ukuran tabal atau tipis. Untuk membuatnya menjadi kaku dapat ditempelkan pada bidang triplek tipis. Dengan media karet ini mudah mengeksplorasi tekstur, yaitu tekstur nyata dan berelief, dengan menggunakan alat penghantar panas. Mudah menciptakan gradasi garis, variasi arah, kepadatan dan kedalaman garis dalam funsinya melahirkan tekstur dan citra objek berdasarkan rujukan gambar digital. Lebih dari itu juga dapat melahirkan efek artistik ketika terkena cahaya lampu.

Sejalan dengan efektivitas media karet, pengunaan alat penghantar panas juga efektif dalam mewujudkan gagasan penciptaan. Banyak kemungkinan yang dapat digunakan, baik alat yang dibuat khusus ataupun alat apa saja yang ada di sekitar kita. Alat yang diciptakan khusus tentunya dibentuk untuk keperluan tertentu, termasuk yang sudah ada di pasaran, seperti alat solder. Sementara untuk alat yang tidak dibentuk secara khusus, dapat menggunakan alat apa saja yang tentunya bentuknya tidak beraturan, namun dapat mewujudkan konsep penciptaan. Potensi semua alat ini terletak pada ujungnya, yang dibuat tebal atau tipis, runcing atau tumpul, petak atau bulat, dan sebagainya. Dalam pengoperasiannya dapat dikondisikan, panas atau sedang, tekanan kuat atau pelan, dibuat lurus atau melingkar. Orientasi perekayasaan alat ini, disamping untuk memanipulasi tekstur, adalah untuk memperkuat citra objek yang sebelumnya dikembangkan secara digital. Berdasarkan hasil penelitian, penggunaan alat penghantar panas ini melahirkan efek yang khas dan artistik yang tidak mudah didapatkan dengan alat lain.

Efektivitas penggunaan media tentunya terkait dengan proses estetis, karena pada hakekatnya semua media yang digunakan diorientasikan untuk mendukung kualitas estetis. Proses estetis diaktualisasikan melalui pengolahan unsur-unsur seni rupa, setidaknya berupa garis, bidang, warna, ruang, dan tekstur. Sebagai mekanisme kontrol, diterapkan prinsip yang dapat menjaga dan memberi arah kualitas estetis, yaitu berupa kesatuan, keseimbangan, irama, pusat perhatian, dan sebagainya. Berdasarkan metode penciptaan kreatif, proses ini cenderung berada pada tahapan eksekusi, konfirmasi, dan validasi. Secara keseluruhan proses ini sudah dimulai ketika pengolahan alternatif 
rujukan objek lukisan melalui rekayasa digital, kemudian dilanjutkan pada proses pemindahan gambar rujukan pada tafril karet. Yang paling menentukan adalah pada proses pewernaan, dimana kelemahan pada proses sebelumnya dapat ditutupi pada proses terakhir ini sampai finishing. Proses pewarnaan dapat membentuk karakteristik lukisan sesuai konsep penciptaan. Misalnya, untuk mengimbangi kesan magis dari bentuk seni rupa etnik yang rujuk dapat dibuatkan nuansa warna cerah yang kontras.

\section{Kontribusi Hasil Ciptaan}

Penciptaan seni lukis berbasis bentuk-bentuk seni rupa dan artefak budaya etnik ini malahirkan upaya pelestarian dan pengembangan karagaman dan kekayaan budaya visual masa lalu. Hal ini sangat penting, mengingat beberapa bentuk dan jenis budaya visual masa lalu tidak dikenali lagi oleh generasi sekarang. Bentuk seni rupa etnik yang merupakan bagian dari budaya visual masa lalu pada umumnya merupakan produk pakai, yang sekarang sudah tergantikan oleh produk baru pabrikasi dengan teknologi modern. Salah satu upaya pelesteriannya adalah dengan mengeksplorasinya menjadi karya seni lukis berkarakter lokal. Sejalan dengan upaya ini, tentunya juga bentuk-bentuk budaya visual masa lalu akan terinventarisasi dan terdokumentasikan dengan baik.

Secara teknis, seni lukis eksploratif ini melahirkan beberapa aspek kreativitas baru, yaitu melalui penggunaan teknologi digital dan matra karet sebagai tafril lukisan. Biasaya tafril lukisan adalah berupa kanvas material kain, sebagaimana bentuk kanvas yang populer dalam gerakan seni rupa modern. Sejalan dengan ini, adalah penggunaan alat penghantar panas untuk mengeksplorasi tekstur dan citra lukisan. Sesuatu yang khas dari bentuk lukisan ini adalah penerapan garis dari goresan alat penghantar panas. Variasi garis dapat diolah sedemikian jauh, sehingga menjadikan lukisan yang kaya garis. Dalam konteks ini, garis dapat mendukung kualitas tekstur, garis juga dapat menjadi perintang warna sebagaimana teknik yang biasa dikenal dalam membatik. Di samping itu, garis berperan dalam pengolahan kontur dan citra lukisan.

Seni lukis hasil penelitian terapan ini berkontribusi dalam banyak hal. Di tengah maraknya perkembangan budaya modern dan kondisi dunia yang sudah mengglobal, orang cenderung lupa dengan tradisi budaya etniknya. Dengan demikin, pengembangan seni lukis ini dapat menjadi sarana untuk mengangkat dan memperomosikan karakter bentuk dan nilai-nilai budaya lokal, khususya Batak Toba. Hal ini akan menjadi stimulir kreatif untuk pengembangan media dan penggunaan alat baru, sekaligus menjadi model dalam pengembangan industri kreatif di Sumatera Utara.

Modernisasi dan globalisasi dicirikan oleh ungkapan nilai dan budaya yang seragam. Identitas dan jati diri tidak akan pernah ditemukan dalam budaya modern dan dunia yang mengglobal. Oleh sebab itu, pengembangan seni lukis ini berkontribusi pada penguatan identitas lokal dan jati diri sebagai bangsa yang kaya budaya. Secara spesifik, karya seni lukis berbasis budaya etnik ini diharapkan berkontribusi memperkaya khasanah budaya rupa nasional, dan berkontribusi dalam wacana seni rupa dunia.

\section{SIMPULAN}

Eksplorasi kreatif dalam rangka melestarikan bentuk-bentuk budaya rupa etnik dalam penciptaan seni lukis modern Sumatera Utara telah menghasilkan beberapa hal. Sesuai dengan masalah dan tujuan penelitian ini, hasil penelitian menunjukan bahwa berdasarkan tema atau content-nya, eksplorasi seni lukis modern Sumatera Utara melahirkan karakter bentuk yang orisinil. Orisinalitas bentuk dimaksud didukung oleh upaya konsisten untuk tetap memperhatikan karakter asli dari bentuk seni rupa etnik yang dirujuk. Seni lukis hasil pengembangan ini berpotensi menjadi penanda jati diri dan promosi karakter budaya rupa etnik, khususnya Batak Toba. Lebih dari itu, karakter seni lukis eksploratif ini berkontribusi pada pengayaan budaya rupa nasional dan peningkatan martabat budaya bangsa. Dalam hal penerapan teknologi modern, hasil penelitian juga menemukan efektivitas penggunaan teknologi digital untuk melahirkan berbagai alternatif rujukan objek lukisan. Begitu juga dengan penggunaan media karet sebagai tafril lukisan, dan rekayasa alat penghantar panas sebagai pembentuk tekstur dan citra lukisan. Semuanya itu dapat memberi stimulasi untuk penggunaan media alternatif dalam pengembangan model industri kreatif di Sumatera Utara.

\section{DAFTAR RUJUKAN}

Burhan, M.A. (Nopember 2018), "Seni Rupa Kontemporer Indonesia dan Multikulturalisme: Keberagaman dan Kontradiksi Satiris", dalam Prosiding Seminar Seni Rupa Universitas Negeri Medan, Medan.

Dharsono. (Nopember 2018), "Indonesia Masa Depan Adalah Indonesia Masa Lalu yang Kreatif”, dalam Prosiding Seminar Seni Rupa Universitas Negeri Medan, Medan.

Djatiprambudi, D. (2007), Menggugat Seni Murni, Lembaga Penebitan Fakultas Bahasa dan Seni Universitas Negeri Surabaya, Surabaya.

Harissman dan Suryanti. (Maret 2019), "Visualisasi Rumah Gadang dalam Ekspresi Seni Lukis", dalam Jurnal Panggung, XIX/01, ISBI Bandung, Bandung.

Long, C.P. (2001), “Art's Fateful Hour: Benjamin, Heidegger, Art and Politics", dalam New German Critique, 83 Special Issue on Walter Benjamin.

Piliang, Y.A. (2018), Medan Kreativitas: Memahami Dunia Gagasan, Cantrik Pustaka, Yogyakarta. 
Sachari, A. (2007), Budaya Visual Indonesia, Penerbit Erlangga, Jakarta.

Shultz, Derald. (Agustus 2008), How Creative Process Work, Media Rail Design, Inc. http://www.creativelatitude.com/article-schultz

Sirait, B. (1980). Pengumpulan dan Dokumentasi Ornamen Tradisional di Sumaatera Utara. Laporan Penelitian, Pemerintah Daerah Provinsi Sumatera Utara.

Sofyan, A.N., dkk. (Desember 2018), "Kerajinan Payung Geulis sebagai Kearifan Lokal Tasikmalaya”, dan Jurnal Panggung, XVIII/04, ISBI Bandung, Bandung.

Triyanto, R. dkk. (2015), Seni Lukis Medan: Potensi dan Perkembangannya, Unimed Press, Medan.

Wahid, J. \& Alamsyah, B. (2013), Arsitektur dan Sosial Budaya Sumatera Utara, Graha Ilmu, Yogyakarta.

Yulinis, Y. (2019). Eksistensi Payung Dalam Kebudayaan Minangkabau Di Era Globalisasi. Mudra Jurnal Seni Budaya, 34(2), 275-283. https://doi.org/10.31091/mudra. v34i2.711

Zulkifli dan Ridwan, M. (Mei 2019), "Revitalization of the Traditional Values Lost Due To the Commodification of Art/Crafts: A Case Study of Bataknese Traditional Ulos", dalam Asian Ethnicity, XX/03, Routledge, London.

Zulkifli. (2016). Komodifikasi Seni Kriya Tradisional Batak dalam Perspektif Strukturalisme. Desertasi FISIP Universitas Airlangga, Surabaya. 